This item was submitted to Loughborough's Research Repository by the author.

Items in Figshare are protected by copyright, with all rights reserved, unless otherwise indicated.

\title{
Securitization and credit quality
}

PLEASE CITE THE PUBLISHED VERSION

http://dx.doi.org/10.2866/696711

PUBLISHER

(c) European Central Bank

VERSION

VoR (Version of Record)

\section{PUBLISHER STATEMENT}

This work is made available according to the conditions of the Creative Commons Attribution-NonCommercialNoDerivatives 4.0 International (CC BY-NC-ND 4.0) licence. Full details of this licence are available at: https://creativecommons.org/licenses/by-nc-nd/4.0/

\section{LICENCE}

CC BY-NC-ND 4.0

\section{REPOSITORY RECORD}

Kara, Alper, David Marques-lbanez, and Steven Ongena. 2019. "Securitization and Credit Quality". figshare. https://hdl.handle.net/2134/24590. 


\section{Working Paper Series}

Alper Kara, David Marques-Ibanez, Steven Ongena

\section{Securitization and credit quality}

\section{No 2009 / February 2017}

Disclaimer: This paper should not be reported as representing the views of the European Central Bank (ECB). The views expressed are those of the authors and do not necessarily reflect those of the ECB. 


\begin{abstract}
Banks are usually better informed on the loans they originate than other financial intermediaries. As a result, securitized loans might be of lower credit quality than otherwise similar nonsecuritized loans. We assess the effect of securitization activity on loans' relative credit quality employing a uniquely detailed dataset from the euro-denominated syndicated loan market. We find that, at issuance, banks do not seem to select and securitize loans of lower credit quality. Following securitization, however, the credit quality of borrowers whose loans are securitized deteriorates by more than those in the control group. We find tentative evidence suggesting that poorer performance by securitized loans might be linked to banks' reduced monitoring incentives. From our findings it follows that current iniciatives on risk retention by the originator, and more detailed loan-by-loan information on loan credit quality would be useful to reap out the benefits of securitization.
\end{abstract}

JEL Classification Numbers: G21; G28

Keywords: Securitization; credit risk; European market 


\section{Executive Summary}

Securitization has been perceived as a major contributing factor to the 2007-2009 financial crisis (Financial Crisis Inquiry Commission, 2011). Following the crisis, U.S. authorities have investigated a number of banks over claims related to selling loans of lower credit quality to unsuspecting investors.

What is the impact of securitization on loans' credit quality? Have banks sold, through securitization, poor quality loans to unsuspecting outsiders? This paper aims to contribute to this discussion by comparing the credit quality of securitized and non-securitized loans and tracking their differences in performance over time.

We focus on the European market which, we believe, is a good laboratory to assess the impact of securitization on credit quality. In Europe the securitization markets started very timidly in the late 1990s, and developed significantly only from 2004 to 2007. The sudden appearance of securitization in Europe probably allows for a clearer assessment of its effects on the banking behavior and the financial system than in the U.S., where the use of securitization has been widespread since the late 1960s.

In practical terms, we contrast the future credit performance of securitized versus non-securitized loans which, prior to securitization, were very similar in terms of their observable characteristics (such as risk, price, maturity, size etc.). We use of a unique dataset that allows us to identify those loans that were eventually securitized. We first link the probability of loan securitization to a set of loan, borrower and lender characteristics. We then track changes in loans' credit quality as measured by borrowers' expected default frequencies $(E D F)$, as measured by Moody's KMV.

We find that at issuance, and based on observable characteristics, originating banks do not seem to select and securitize lower quality corporate loans to outside investors. Yet following securitization, the credit quality of borrowers whose loans are securitized deteriorated by more than those whose loans were not securitized. While this underperformance could be due to a number of causes, we provide some tentative evidence suggesting that the poorer performance of securitized loans might be linked to banks' reduced incentives to monitor securitized loans. 


\section{Introduction}

Banks generate proprietary information and tend to have superior knowledge on the credit quality of the loans they originate. As a result, banks might have an incentive to securitize loans of lower credit quality to unsuspecting investors (Gorton and Pennacchi, 1995). Largely for this reason, securitization has been perceived as a major contributing factor to the 2007-2009 financial crisis (Financial Crisis Inquiry Commission, 2011). Following the crisis, authorities have investigated a number of banks over claims related to mis-sold securitized loans. ${ }^{1}$

In this direction, recent empirical evidence suggests that banks tend to securitize the riskier mortgages of their portfolio (see for instance Krainer and Laderman, 2014; Elul, 2015). Yet, evidence on the impact of securitization on corporate loans on credit quality remains very limited, it is circumscribed to the U.S. and seems to offer contradictory results (Benmelech et al., 2012; Bord and Santos, 2015; Wang and Xia, 2015).

We assess the credit quality of securitized loans on the euro-denominated corporate loan market. In practical terms, we contrast the credit performance of securitized versus nonsecuritized loans over time. We link the probability of loan securitization to a set of loan, borrower and lender characteristics and track changes in loans' credit quality as measured by borrowers' expected default frequencies. In the robustness checks we also employ alternative methodologies — including propensity score matching — to compare the credit risk of securitized

\footnotetext{
${ }^{1}$ For instance, JP Morgan and Bank of America agreed to pay USD 4.5 and 9.1 billion, respectively, to settle court cases with institutional investors regarding miss-sold mortgage-backed securities (MBS). The U.S. Federal Housing Finance Agency reached settlements of around USD 16.5 billion with eighteen major financial institutions alleged to be involved in securities law violations and fraud in the sale of MBS to Fannie Mae and Freddie Mac. On a separate case, Citigroup and JP Morgan Chase agreed to pay around USD 15 billion to the U.S. Department of Justice over allegations related to misled investors on MBS during the time leading up to the 2007-2009 crisis.
} 
and non-securitized corporate loans which, prior to securitization, were very similar in terms of their observable characteristics.

We use a unique dataset obtained directly from securitization trustees operating in the European Union (EU). We construct this dataset by getting access to the portfolios of the majority of euro-denominated collateralized loan obligations (CLOs) so we have a representative picture of the market, which includes public as well as private deals. Our detailed loan level dataset allows us to distinguish, among all syndicated loans, those that were eventually securitized.

We focus on the euro-denominated CLO market which, we believe, is a good laboratory to assess the impact of securitization on credit quality. In Europe the securitization markets started very timidly in the late 1990s, and developed significantly only from 2004 to 2007. In contrast, in the U.S. the introduction and growth of securitization markets has been much more continuous over time. The sudden appearance of securitization in Europe probably allows for a clearer assessment of its effects on the banking behavior and the financial system than in the U.S.

Concentrating on corporate loan securitization also provides a useful perspective as most of the existing securitization literature focuses on the mortgage market. Mortgage lending, tends to be relatively mechanical and the credit risk of mortgage backed securities (MBS) is heavily reliant on housing prices. In contrast, corporate lending decisions are more dependent on idiosyncratic, and often proprietary, information on the credit quality of borrowers that is often obtained over time via lending relationships. In other words, information asymmetries are likely to be particularly pronounced in the securitization of corporate loans as the idiosyncratic risk of individual borrowers — which is often difficult to ascertain for outside investors in comparison to 
the mortgage market - plays a large role. ${ }^{2}$ As a result, the screening and monitoring by the lender of individual borrowers would be expected to have a bigger impact on the performance of corporate loans after securitization than for other types of loans.

We find that, based on borrowers' publicly available information at issuance, originating banks do not seem to select and securitize lower quality corporate loans to outsiders. Following securitization, however, the credit quality of borrowers whose loans are securitized deteriorated by more than those in the control group. While this underperformance could be due to a number of causes, we provide some tentative evidence suggesting that the poorer performance of securitized loans might be linked to banks' reduced incentives to monitor securitized loans.

The remainder of the paper is organized as follows: Section 2 briefly reviews and draws hypotheses from the related literature. Section 3 describes the data sources and explains the empirical methodology used in the analysis. The results of estimations are presented and discussed in Section 4. Section 5 concludes.

\section{Literature and Hypotheses}

There is significant evidence from the U.S. suggesting that banks that resorted more intensively to securitization activity in the years prior to the crisis relaxed their lending standards more aggressively than other institutions (Keys et al., 2011; Dell'Ariccia, 2012; Nadauld and Weisbach, 2012). There is also evidence linking securitization activity and increases in bank

\footnotetext{
${ }^{2}$ At the same time, syndicated loans are sizable and, unlike other types of, their terms are usually publicly announced when the deals are signed by consortium of banks and the borrower so there is usually more information available than for other types of loans (see Sufi, 2007, on the dynamics of syndicated loan formation). For instance during the process of structuring and placing deals the underwriters and originators of the deal provide extensive information to investors which allows them to broadly assess the riskiness of the loans underlying the CLO. However, in comparison to mortgage securitization, which is mostly driven by economic fundamentals and house prices, it continues to be more complicated for investors to value each and every corporate loan underlying the security.
} 
risk-taking (Goderis et al., 2007; Instefjord, 2005; Haensel and Krahnen, 2007), and augmented systemic risk (Michalak and Uhde, 2013; Krahnen and Wilde, 2008; Brunnermeier and Sannikov 2014; Wagner, 2007). ${ }^{3}$

In contrast, other studies do not find evidence suggesting that securitization led to riskier lending activities (Shivdasani and Wang, 2011 for leveraged buyouts; Casu et al., 2013 for overall bank risk; Albertazzi et al., 2015 for the Italian market; Kara et al., 2016 for Europe). There is also literature that underlines the potential benefits of securitization suggesting that it supports financial stability by smoothing out risks among many investors (Duffie, 2008), improving banks' ability to manage credit risk (Cebenoyan and Strahan, 2004) and increasing banks' profitability (Jiangli et al., 2007).

More closely related to our paper, some of the empirical work examines the performance of loans after they have been securitized although evidence is limited and, at times, inconclusive. Some of these studies suggest that in the U.S. the credit quality of securitized corporate loans is not worse than that of non-securitized loans (Benmelech et al., 2012; Wang and Xia, 2015). ${ }^{4}$ Alternatively there is also evidence that finds inferior credit performance for securitized loans after securitization (Bord and Santos, 2015). For the mortgage market, recent results suggest that in the U.S. banks securitized ex-ante their riskiest mortgages, and that following securitization the delinquency rates for securitized mortgages were higher than for non-securitized (Krainer and Laderman, 2014; Elul, 2015). On the other hand, looking at the pre-crisis period, Ambrose et

\footnotetext{
${ }^{3}$ There is also evidence showing that securitization inhibits distressed borrowers' loan renegotiations (Piskorski et al., 2010).

${ }^{4}$ These authors report some evidence of under-performance for securitized loans originated between 2005 and 2007 although they suggest that this is not consistent across samples, performance measures, and horizons.
} 
al., (2005) show that in the U.S. securitized mortgages experienced lower ex-post defaults than those retained by banks.

We analyze whether banks securitized their lower quality euro-denominated corporate loans in the build up to the 2007-2009 financial crisis. Information asymmetries on the credit quality of borrowers between originating banks and purchasers of CLOs provide banks with the initial opportunity to do so as originators are likely to have more information about borrowers than the buyers of the CLOs. This is either because they have particular experience lending to that sector, or because they have a lending relationship with the borrower that allows them to collect proprietary information about those borrowers over time. From an investor's perspective, a related argument is that even sophisticated investors might have neglected tail risks (Gennaioli et al., 2012).

The credit cycle is also likely to play a significant role in this setting. During good states of a credit cycle (i.e., upswing of the credit cycle), investors might be more willing to acquire riskier securities. It could also be that during credit expansions it is more difficult for investors to assess the true value of information intensive securities - such as $\mathrm{CLOs}^{5}$ as suggested by the extensive literature on adverse selection (Akerlof, 1970) — during credit booms (Dang et al., 2012; Santos, 2015; Demyanyk and Van Hemert, 2011).

In stark contrast, other studies suggest that banks might also have an incentive to securitize only those loans that are of intrinsic better credit risk in order to signal the quality of the securities (Greenbaum and Thakor, 1987; DeMarzo, 2005; Instefjord, 2005). Banks may also have an incentive to securitize less risky loans thereby increasing their risk profile for a given

\footnotetext{
${ }^{5}$ There is, in fact, evidence suggesting that investors did not have accurate models for pricing securitized debt,
} particularly CDOs (Jarrow et al., 2007). 
level of capital (Calem and LaCour-Little, 2004). Maintaining their long-term reputational capital in the securitization market might induce banks to sell their loans of relatively better quality (Albertazzi et al., 2015). The signaling hypothesis would therefore suggest that based on observables at the time of issuance, originating banks would be securitizing those loans with lower credit risk. Hence we first test the following signaling hypothesis:

H1. At issuance securitized corporate loans are of better credit quality than, otherwise similar, non-securitized loans.

After securitization, originating banks might have fewer incentives to monitor borrowers as loans are passed on to outside investors. As a result, over time securitized loans would perform worse than non-securitized ones as the originating bank would monitor securitized loans less intensively (Petersen and Rajan, 2002). Supporting this view, some studies associated loan sales and securitization to looser credit monitoring (Gorton and Pennacchi, 1995; Duffee and Zhou, 2001; Morrison, 2005; Parlour and Plantin, 2008; Chiesa, 2008; Kamstra et al., 2014; Wang and Xia, 2015). We aim to test these arguments with the following two hypotheses:

H2. Credit quality of securitized loans evolves differently after securitization compared to nonsecuritized loans.

H3. Over time securitized corporate loans perform worse than non-securitized loans due to banks' reduced monitoring incentives (Monitoring hypothesis).

First, we examine whether there is a difference in the performance of loans when they are securitized. Second, to test the monitoring hypothesis we track and compare the ex-post credit risk of loans that are securitized versus those which are non-securitized. Further, we focus on those loans for which bank monitoring may have a more significant bearing on borrowers' credit performance. We conjecture that collateralized loans, where assets are pledged to the bank by the 
borrower, do not require as much monitoring as non-collateralized ones (Bester, 1985; Cerqueiro et al., 2015). This is because the borrower, having her assets at stake, would be less likely to engage in risk-shifting behavior at the expense of the lender and show, as a result, a better performance. If the monitoring hypothesis holds, for the sub-group of collateralized loans one would not expect a difference in credit performance for similar loans only on the basis of whether loans are securitized or not. Also within the non-collateralized sub-group, securitized loans would tend to perform poorly in comparison to the non-securitized ones. This is because the bank, having sold the loan, is less likely to devote many resources to monitor the borrower intensively and, at the same time, the borrower has not pledged assets in the form of collateral that would discourage risk-taking.

Another possible explanation for the relative poor credit performance of securitized loans after securitization may be that banks are able to exploit their information advantage. Banks may securitize apparently better loans based on publicly observable characteristics, in order to signal quality while still exploiting their information advantage over outsiders. In fact, the signaling argument relies on the fact that outsiders could only roughly assess the credit quality of the borrower through observable indicators such as credit ratings or accounting statements. In contrast banks may possess a more accurate view on the future performance on the loans they originated due to their access to proprietary information on the borrower. Hence, banks would have an incentive to use this information and securitize apparently good loans — as could be inferred by outsiders from the observable characteristics of borrowers at the time of securitization - as the originating bank would expect those loans to perform worse compared to the expected path of performance as inferred by outside market observers. For example, there is evidence from trading in the secondary market of mortgage-backed securities suggesting that 
banks exploit their access to inside information (Drucker and Mayer, 2008) and that prior to securitization, mortgage lenders adversely selected higher prepayment risk mortgages (Agarwal et al., 2012).

This could be termed as the lemons hypothesis where over time securitized loans perform worse than non-securitized loans due to banks' ability of exploiting their information advantage over outside investors. In our setup, an inferior performance of securitized compared to nonsecuritized loans for both collateralized and non-collateralized instruments would be consistent with the lemons hypothesis, although it is difficult to rule out other possibilities that are not captured in our analysis.

\section{Data and Methodology}

\subsection{Data}

Data on loan deals is obtained from Dealogic-Loanware. It includes euro-denominated syndicated loans granted by euro-area banks between 2004 and 2007 to non-financial corporations headquartered in the euro area. Data on securitization activity comes from Dealogic-Bondware and Standard \& Poor's. ${ }^{6}$ We limit our sample to funded and cash-flow (balance-sheet) CLOs issued by banks headquartered in the euro area ${ }^{7}$ and exclude refinancing and loans granted to finance M\&A activities. We add two additional fields to our dataset, which allow us to identify among all syndicated loans, those that were eventually securitized. We do this by collecting loan-by-loan confidential information from all major European Trustees for

\footnotetext{
${ }^{6}$ An advantage of using Bondware and Standard \& Poor's as the source for securitization data is that the names of the originator, date of issuance and deal proceeds are all registered.

${ }^{7}$ We exclude CLOs by non-bank institutions as our interest is on the effects of securitization on bank lending and monitoring.
} 
loans issued between 2004 and 2007. In our sample, 1,795 out of 4,652 syndicated loans extended during this period were subsequently securitized. ${ }^{8}$

We carefully match our database on syndicated loans with information on the expected probability of default $(E D F)$ of each borrower underlying each loan from 2005 to 2010. The $E D F$, computed by Moody's KMV, is a forward-looking firm-specific measure of the actual probability of default calculated using a structural approach which builds on Merton's model to price corporate bond debt (Merton, 1974). ${ }^{9}$ The final EDF value, expressed as a percentage, represents the implied risk of default and is constructed by combining companies' financial statements with stock market information and a proprietary default database maintained by Moody's KMV. EDF developments are regularly used as an indicator by financial institutions, investors, central banks and regulators to monitor credit risks of borrowers.

Compared to other measures of expected bank risk, the KMV methodology has various advantages. First, it is not based on ratings which might be biased indicators of corporate risk due to conflicts of interest (Bolton, 2012). Second, unlike measures of default risks derived exclusively from accounting information — such as Z-scores-, EDFs are not a backwardlooking indicator of risk. Third, despite their simplifying assumptions, EDF estimations of default risk show strong robustness to model misspecifications (Jessen and Lando, 2015).

During the recent financial crisis and compared to other measures of default risk, the $E D F$ has done relatively well as a predictor of firms' risk on a cross-sectional perspective. That is, the relative positions of firms ranked according to their $E D F$ levels in the year before the

\footnotetext{
${ }^{8}$ We only consider loans securitized from 2004 and 2007 as during the financial crisis the public CLO market ground to a halt. We do not consider the CLOs constructed to obtain central bank liquidity during the crisis. ${ }^{9}$ More specifically, the calculation of $E D F$ builds on Vasicek and Kealhofer's extension of the Black-ScholesMerton option-pricing.
} 
crisis were good predictors of rank ordering of default risk during the crisis (Munves et al., 2010). Analyzing the EDF performance in the crisis period both Korablev and Qu (2009) and Gokbayrak and Chua (2009) find that EDF predictive power of default risk is as good as or better than CDS spreads on their respective samples.

KMV best applies to publicly traded companies for which the value of equity is available and determined by the financial markets. By matching our syndicated loan database to those borrowers for which an $E D F$ measure is available reduces our sample to those borrowers that are listed on the stock market. ${ }^{10}$ We use borrowers' $E D F$ changes over time to measure the change in credit quality. (Munves et al., 2000). An increase in a firm's EDF could well signal greater default risk, even if the current absolute level might be excessive compared to a user's actual exposure. In this way $E D F$ metrics can provide early warning of impending difficulties ${ }^{11}$.

\subsection{Model and Variables}

We first estimate a logistic model that links the probability of loan securitization to certain loan and borrower characteristics:

$$
\operatorname{Pr}\left(\text { securitized }_{i}=1 \mid \mathrm{X}\right)=\Phi\left(\alpha E D F+\delta \Delta E D F+L^{\prime} \theta+Z^{\prime} \gamma\right)
$$

Where $P r$ is the probability of securitization for loan $I$ in the year following its issuance, $\Phi$ is the standard cumulative normal probability distribution, $L$ is a set of variables controlling

\footnotetext{
${ }^{10}$ For those observations where the borrower has defaulted after the loan issuance are included in our analysis until the period of default as we use the differences in $E D F$ to measure borrowers' performance.

${ }^{11}$ It is worth to note here that Moody's KMV model does not adjust for the securitization status of the companies' loans.
} 
for loan characteristics, and $Z$ is another set of variables controlling for other factors expected to impact on the probability of default. Loan characteristics include: loan spread (basis points), loan size (natural logarithm), maturity (years), presence of guarantees, collateral, instrument type, loan purpose (corporate use, capital structure, project finance, transport finance and property finance). We control for industry (construction and property, high-tech industry, infrastructure, population related services, state, manufacturing and transport) and date of issuance. We also take into account bank and syndicate characteristics as they might also impact on the probability of securitizing a loan (Sufi, 2007). We control for bank profitability, as there is evidence suggesting that less profitable banks are more likely to securitize loans (Casu et al., 2013). We control for the impact of lead banks' characteristics via fixed effects by identifying 75 groups of top 20 lead banks that often participate into loan syndications -alone or collectively — in the European market. We control for syndicate size using the number of banks included on the syndicate.

We track changes in $E D F(\triangle E D F)$ to proxy for the deterioration or improvement in borrowers' credit quality (henceforth performance) over time. Using this variable we examine the ex-post (i.e., after the loan has been securitized) credit performance of the loan controlling for observable characteristics at the time of origination. We use three alternative measures of $\triangle E D F$

1. $\triangle E D F_{A}$ accounts for changes in credit risk for three time periods (one, two and three years) starting from the year in which the loan is issued. For example, to calculate a 2-year forward $\triangle E D F_{A}$ for a loan issued in 2005, we take the difference in $E D F$ for that borrower by subtracting the average $E D F$ values of 2007 and 2005. 
2. $\triangle E D F_{B}$ measures the differences in $E D F$ between the year in which the loan is issued and three different time periods (i.e., 2008, 2009 and 2010) selected to take place during the financial crisis. For example, assume that loan $A$ is issued in 2005 and loan $B$ is issued in 2006 , to compute the $\triangle E D F_{B}$ for year 2008 for loan $A$, we take the difference between the $E D F$ in 2008 and 2005. For loan $B$, we take the difference in $E D F$ between 2008 and 2006. This alternative measure allows us to consider $E D F$ changes from the time of securitization to different stages of the financial crisis.

3. $\triangle E D F_{C}$ measures the change in borrowers' credit risk during the financial crisis. To account for this, we incorporate the $\triangle E D F$ for each borrower calculated as changes in $E D F$ from the start of the financial crisis (third quarter of 2007) to three separate periods of the financial crisis (i.e., 2008, 2009 and 2010). For example, to calculate the $\triangle E D F_{C}$ for 2008 , we take the difference between the average $E D F$ in 2008 and that of the third quarter of 2007. The idea is that many of the inherent risks in a securitization structure could be of systemic nature and materialize only in the event of a (large) financial crisis.

\subsection{Propensity Score Matching}

The analysis of the effect of securitization on loans' credit quality might raise self-selection concerns with regard to the decision to securitize certain loans. If credit performance of securitized and non-securitized loans would have differed systematically regardless of securitization, comparing credit risk of securitized and non-securitized loans might yield biased estimates on the impact of securitization. Under this assumption, if securitized loans are found to perform differently, on average, than non-securitized ones, the difference may be due to the 
effect of self-selection rather than to securitization. Strictly speaking, to test our hypothesis, we would need to know what would have happened to the credit quality of securitized loans had they had not been securitized. Because it is impossible to observe the same loan in both states of the world, we need to find an appropriate proxy for the counterfactual performance of securitized loans. Good candidates to proxy for this counterfactual are non-securitized loans from which we construct our control group. We construct this control group using a propensity score matching (PSM) approach (Rosenbaum and Rubin, 1983) which allows us reduce the matching problem to a single dimension via the propensity score.

We match our loan sample using propensity scores to compare securitized and nonsecuritized loans, which are ex-ante (i.e., prior to securitization) similar in terms of their key observable characteristics most related to the probability of securitization. Importantly our control group — constructed from the non-securitized loans - is selected among those loans whose credit risk trajectory prior to securitization lies as close as possible to that of similar securitized loans. If we assume that there are no significant differences in unobservables between the two matched groups of loans — or that unobservables do not play a significant role on the potential outcome - the observed differential in performance $(\triangle E D F)$ can be attributed to the effect of having received the treatment, which in our setting is the securitization of the loan.

Through matching we restrict our inference to the sample of securitized and matched non-securitized loans. The impact of the treatment (securitization) on loan $i$, $\delta_{i}$, is the difference between potential outcomes $(\triangle E D F)$ with and without treatment:

$$
\delta_{i}=\Delta E D F_{1, i}-\Delta E D F_{0, i}
$$

The impact of securitization over the sample would be the average treatment effect on the treated $(A T T)$, computed as follows: 


$$
A T T=E\left(\Delta E D F_{1}-\Delta E D F_{0} \mid T=1\right)
$$

As indicated, the treated group (securitized loans, denoted $T_{i}=1$ for loan $i$ ) is matched with a control group (non-securitized loans, denoted $T_{i}=0$ for loan $i$ ) on the basis of its propensity score which is a function of loan and borrower observable characteristics:

$$
P\left(X_{i}\right)=\operatorname{Pr}\left(T_{i}=1 \mid X_{i}\right), \text { with }\left(0<P\left(X_{i}\right)<1\right)
$$

In our setting the propensity score, $P\left(X_{i}\right)$, is initially estimated with a probit model where the binary dependent variable has a value of one for securitized loans, and zero otherwise. The regressors, $X_{i}$ include credit quality prior to securitization, loan characteristics - loan purpose, business industry, maturity and size — as well as bank, year and country dummies.

There needs to be sufficient overlap in the propensity scores to match securitized and non-securitized loans. We impose a common support condition $\left[\left(0<P\left(X_{i}\right)<1\right)\right]$ that restricts inference to treated and non-treated units with comparable propensity scores. That is, non-treated units whose propensity scores are lower (or higher) than the defined minimum (maximum) are dropped. We exclude loans that have a 0 or 1 propensity scores to satisfy the overlap condition of the treatment and control samples. We employ nearest-neighbor matching where each securitized loan is matched with those non-securitized loans with the closest propensity scores (Dehejia and Wahba, 2002):

$$
C(i)=\min \left|p_{i}-p_{j}\right|
$$

where by $C(i)$ is the set of control loans with an estimated value of the propensity score $p_{i}$, matched to securitized loan $i$. We calculate our control group using matching with and without replacement. ${ }^{12}$ This allows us to increase the quality of the matching and decrease bias

\footnotetext{
${ }^{12}$ In the latter case a non-securitized loan can be used as a match more than once
} 
(Dehejia and Wahba, 2002). Our main results are constructed using one to one (1:1) matching where each securitized loan is matched with a single non-securitized loan. We also calculate results for two (1:2) and four (1:4) matches. Increasing the number of matches might also increase bias — as the second and fourth closest matches are usually further away from the treated loan than the first match. At the same time the use of multiple matches can decrease variance as the matched sample becomes larger (Rubin and Thomas, 2000).

\section{Results}

Descriptive statistics are presented in Table 1. In Panel A we display the mean, median, standard deviation and mean comparison (t-tests) of loan and borrower characteristics. We find that securitized loans tend to be smaller in size and have a longer maturity than non-securitized loans. The number of banks in the loan syndicate and the ratio of banks active in securitization (to total banks) in the syndicate are almost identical for both groups. EDFs of companies whose loans are non-securitized are usually higher than for companies whose loans are securitized. In Panel B we display the summary statistics for the dummy variables. We find that a large share of securitized loans are secured using collateral and tend to be leveraged.

\subsection{Whole Sample}

In Table 2 we present the results for the logistic model by employing only the level of credit risk (i.e., $E D F$ ) at the time of the issuance. Controlling for a set of micro and macro variables, ${ }^{13}$ we find that the $E D F$ coefficient is negatively affected by the probability of loan securitization. This

\footnotetext{
${ }^{13}$ Note that summary statistics on these variables are not reported to keep the tables parsimonious. All these statistics are available upon request.
} 
suggests that loans of borrowers with relatively higher default risk are less likely to be securitized. This finding supports $H 1$, the signaling hypothesis, and shows that banks signal quality by retaining assets of poorer credit risk, as observed at issuance, and tend to securitize assets of initially better credit quality (Greenbaum and Thakor, 1987; DeMarzo, 2005; Instefjord, 2005).

Subsequently, we examine whether there is a performance difference between securitized and non-securitized loans using changes in credit risk. We relate the ex-post performance of borrowers $\left(\triangle E D F_{A}\right)$ to the likelihood of loan securitization to examine the link between probability of securitization and future performance. Results, presented in Table 3, show the $\Delta E D F_{A}$ for sets of one to three year time periods following loan securitization during that year. We report a positive relationship between the ex-post $\triangle E D F_{A}$ and the probability of loan securitization for all time horizons. This suggests that the likelihood of loan securitization is higher for borrowers that showed worse performance.

We present the $\triangle E D F_{B}$ results in Table 4. Here we measure the differences in $E D F$ between the year in which the loan is issued and three time periods (i.e., 2008, 2009 or 2010) chosen to take place during the financial crisis. We find that the coefficient of the $\triangle E D F_{B}$ is significant for all time horizons and suggests that borrowers whose loans are securitized showed inferior performance than loans that were not.

We are also interested in changes in borrowers' relative performance during the financial crisis $\left(\triangle E D F_{C}\right) . \triangle E D F_{C}$ is calculated as the changes in $E D F$ from the start of the financial crisis to three separate periods that take place during the financial crisis. Results — presented in Table 5- show that $\triangle E D F_{C}$ has a positive and significant coefficient for the 2009 and 2010 periods 
and are not significant for 2008. This suggests that loans of borrowers whose default risk would materialize in the event of a systemic crisis were more likely to be securitized. ${ }^{14}$

Subsequently, we design an alternative setup where we use changes in $E D F$ as dependent variable and securitized (equals to 1 if the loan is securitized and 0 otherwise) as a determinant of $E D F$ changes. This may provide a clearer indication of the impact of securitization on future credit performance of the firm. Results are presented for all of our $\triangle E D F$ variables in Table 6. The coefficient of securitized is found to be positive and significant only for the medium term. Results, supporting our second hypothesis (i.e. H2), show that companies whose loans are securitized perform poorly compared to companies whose loans are not securitized. It is worthwhile to also note that size of the coefficients of securitized increases over time.

\subsection{Propensity scores}

As an alternative strategy to assess the robustness of our results we use a propensity score matching. This technique allows us measure the impact of securitization on credit risk using a comparable sample of loans.

To verify the quality of matching graphically we first plot the distribution of the propensity scores for both groups (securitized or non-securitized loans), before and after matching, for the whole sample (Figure 1). In the unmatched sample, the propensity score distribution of the non-securitized loans is skewed to the left. In contrast, in the matched sample

\footnotetext{
${ }^{14}$ We also run linear probability models for robustness to ensure that the possible bias in the logistic model does not drive our results. Results do not change and available upon request.
} 
the distribution of the two groups is similar. This suggests that the use of propensity score matching is appropriate in our context ${ }^{15}$.

Table 7 presents the $\Delta E D F_{A}$ results. We find that for loans of the securitized (treatment) group, the treatment has increased their future $E D F$ for time horizons over 1 year and that the highest impact is seen in year three. In short, it shows that the credit quality of borrowers whose loans are securitized deteriorates significantly in comparison to the control group.

The highest impact is observed after three years as suggested by the coefficients for the average treatment of the treated $(A T T)$. This seems a plausible result as we are looking at loans that already have an observable credit risk indicator (i.e., $E D F$ ). For such loans one would expect that the change in credit quality would take time as outsiders (such as CLO investors) can already assess the initial credit risk as assessed by financial markets via $E D F$ s. In other words, the effect of banks' informational advantage over outsiders would not surface completely in the short-term and would materialize gradually over time.

Table 8 presents $A T T \mathrm{~s}$ results for $\triangle E D F_{B}$. We find that only $\triangle E D F_{B}$ for year 2009 is significant when the treated is matched with four controls. $\triangle E D F_{B}$ was expected to capture the dramatic shift in borrowers' $E D F$ values immediately after the start of the financial crisis in 2008. We only marginally observed that effect in 2009. We present $A T T$ s for $\Delta E D F_{C}$ in Table 9. In line with the results presented above securitized loans performed worse in the post-crisis period, although only the difference in $E D F$ in 2009 is statistically significant.

\footnotetext{
${ }^{15}$ Ex-ante loan characteristics for the matched sample show that the loans are similar across observable characteristics after matching. This table is available upon request.
} 
Thus far our results suggest that loans of borrowers with relatively higher default risk are less likely to be securitized, supporting the signaling hypothesis. We also show that borrowers of securitized loans performed poorly when compared to borrowers of non-securitized loans. There may be two ways to explain these findings. It could be that securitized loans may be performing more poorly due to banks' weaker incentives to carefully monitor borrowers (i.e., monitoring hypothesis). Alternatively, and more speculatively, banks may be exploiting their informational advantage over outsiders. That is, banks might be better able to predict more accurately future performance of the loans and keep as a result the better ones (i.e., lemons hypothesis). We test the monitoring hypothesis (i.e. H3) by examining the performance of borrowers whose loans are more reliant on bank monitoring. We hypothesize that collateralized loans, where assets are pledged against the loan by the borrower, do not require as much monitoring as noncollateralized loans. This is because the borrower, having her assets at stake, would be more vigilant about taking on excessive risks. If the monitoring hypothesis holds, then, there should not be performance differences between similar securitized and non-securitized loans within the sub-group of non-collateralized loans. In addition within the non-collateralized loans sub-group, securitized loans should perform more poorly than non-securitized ones due to bank lesser monitoring incentives. Next section presents our findings for the two sub-groups.

\subsection{Collateralized versus Non-collateralized Loans}

We repeat our analysis and distinguish between those corporate loans requiring and not requiring collateral. Results for logit models for all three versions of $\triangle E D F$ are presented in Table 10. For $\Delta E D F_{A}$ we do not find any significant coefficients for the collateralized loans group (columns IIII). Conversely, in the non-collateralized group, $\triangle E D F_{A}$ is positive and statistically significant 
for all time horizons (columns X to XII). For non-collateralized loans the likelihood of a loan being securitized is higher if the borrower performed poorly after issuance. Results for $\triangle E D F_{B}$ are presented for collateralized (columns IV-VI) and non-collateralized (columns XIII-XV) loans respectively. For all time horizons of $\triangle E D F_{B}$, the results show that borrowers of securitized loans were more likely to perform poorly. We also observe significant negative coefficients for collateralized loans for 2010. These results provide some, albeit weaker, evidence that banks kept collateralized loans that are expected to show an inferior performance in their books rather than securitizing them. Results for $\triangle E D F_{C}$ are shown in columns VII-XI, for collateralized, and XVI-XVIII, for non-collateralized loans. For non-collateralized loans we find significant and positive coefficients for all years. Overall, Table 10 provides tentative evidence suggesting that among securitized borrowers, the $E D F$ of borrowers whose loans were not collateralized increased significantly more compared to borrowers whose loans were collateralized. We also run OLS regressions with our alternative setup where changes in $E D F$ are the dependent variables and securitized is used as an explanatory variable. Results on Table 11 show that securitized loans are more likely to show worse performance if they are non-collaterized. This finding is consistent across all horizons and more significant in the longer term.

In Table 12 we present the results for propensity score matched estimations for the two sub-groups. We find that none of the coefficients for the $\triangle E D F\left({ }_{A},{ }_{B}\right.$ or $\left.{ }_{C}\right)$ variables are significant for loans that are collateralized. For the non-collateralized sample, coefficients of ATT are statistically significant and positively related to the probability of securitization only for $\triangle E D F_{A}$ variables for 2 and 3 year horizons. It is worthwhile to note that for $\triangle E D F_{A}, A T T$ increases over time where the largest difference is reported Year 3. In other words the difference becomes more prevalent in the long-term as the effects of banks' reduced monitoring of the 
borrower gradually start influencing corporates' performance. These findings provide indirect evidence for the monitoring hypothesis. Banks, having sold the loan to third parties, may be less interested in monitoring the borrower which in turn, may have affected the borrower's performance. This interpretation is driven by the fact that we observe more deterioration in credit quality for non-collateralized loans that are securitized. On the other hand, we do not find any evidence for the lemons hypothesis.

\section{Conclusions}

We examine the relative performance of corporate borrowers whose loans were securitized in Europe during the period preceding the financial crisis. We find that banks do not seem to have selected and securitized loans of lower quality to outsiders, providing evidence consistent with the signaling argument. Banks seem to have kept poorer quality corporate loans to signal the quality of the securitized assets to the investors. We also show that following securitization, the credit quality of borrowers whose loans are securitized deteriorated significantly over time compared to the control group. We find that poor performance is possibly linked to the weakening in monitoring activities by banks after securitization as, within securitized loans, noncollateralized ones show worse performance than securitized ones.

In the post-crisis period, European policy makers, recognizing the potential benefits of securitization to the financial system, are considering policy options to transform and revive securitization markets in the EU (European Central Bank, 2014). Having a better understanding of the financial stability implications of securitization can help to develop a robust securitization market. Our results vouch for the advantages of setting up mechanisms to improve the information quality on the collateral pledged by borrowers. These might include credit registers 
with enhanced mark to market information on collateral values. Robust originator risk retention requirements may also help in mitigating the reduced monitoring incentives after securitization. 


\section{References}

Agarwal, S., Chang, Y., Yavas, A., 2012. Adverse Selection in Mortgage Securitization. Journal of Financial Economics 105, 640-660.

Albertazzi, U., Eramo, G., Gambacorta, L., Salleo, C., 2015. Asymmetric Information in Securitization: An Empirical Assessment. Journal of Monetary Economics 71, 33-49.

Akerlof, G.A., 1970. The Market for "Lemons": Quality Uncertainty and the Market Mechanism. The Quarterly Journal of Economics 84, 488-500.

Ambrose, B.W., LaCour-Little, M., Sanders, A.B., 2005. Does Regulatory Capital Arbitrage, Reputation, or Asymmetric Information Drive Securitization? Journal of Financial Services Research 28, 113-133.

Benmelech, E., Dlugosz, J., Ivashina, V., 2012. Securitization without Adverse Selection: The Case of CLOs. Journal of Financial Economics 106, 91-113.

Bester, H., 1985. Screening vs. Rationing in Credit Markets with Imperfect Information. American Economic Review 75, 850-855.

Bolton, P., Freixas, X., Shapiro, J., 2012. The Credit Ratings Game. Journal of Finance 67, 85-111.

Bord, V., Santos, J.A.C., 2015. Does Securitization of Corporate Loans Lead to Riskier Lending? Journal of Money, Credit and Banking 47, 415-444.

Brunnermeier, M.K., Sannikov, Y., 2014. A Macroeconomic Model with a Financial Sector. American Economic Review 104, 379-421.

Calem, P.S., La Cour-Little, M., 2004. Risk-based Capital Requirements for Mortgage Loans. Journal of Banking and Finance 28, 647-672.

Casu, B., Clare, A., Sarkisyan, A., Thomas, S., 2013. Securitization and Bank Performance. Journal of Money, Credit and Banking 45, 1617-1658.

Cebenoyan, A.S., Strahan, P.E., 2004. Risk Management, Capital Structure and Lending at Banks. Journal of Banking and Finance 28, 19-43.

Cerqueiro, G., Ongena, S., Roszbach, K., 2016. Collateralization, Bank Loan Rates and Monitoring: Evidence from a Natural Experiment. Journal of Finance 71, 1295-1322.

Chiesa, G., 2008. Optimal Credit Risk Transfer, Monitored Finance, and Banks. Journal of Financial Intermediation 17, 464-477.

Dang, T.V., Gorton, G., Holmstrom, B., 2012. Ignorance, Debt and Financial Crises, manuscript, Yale School of Management.

Dehejia, H.G., Wahba, S., 2002. Propensity Score-matching Methods for Nonexperimental Causal Studies. The Review of Economics and Statistics 84, 151-161.

Dell'Ariccia, G., Igan, D., Laeven, L., 2012. Credit Booms and Lending Standards: Evidence from the Subprime Mortgage Market. Journal of Money, Credit and Banking 44, 367-384.

DeMarzo, P.M., 2005. The Pooling and Tranching of Securities: A Model of Informed Intermediation. Review of Financial Studies 18, 1-35.

Demyanyk, Y., Van Hemert, O., 2011. Understanding the Subprime Mortgage Crisis. Review of Financial Studies 24, 1848-1880.

Drucker, S., Mayer, C., 2008. Inside Information and Market Making in the Secondary Mortgage Market. Columbia Business School, New York NY.

Duffee, G.R., Zhou, C., 2001. Credit Derivatives in Banking: Useful Tools for Managing Risk? Journal of Monetary Economics 48, 25-54.

Duffie, D., 2008. Innovations in Credit Risk Transfer: Implications for Financial Stability. BIS, Basle. 
European Central Bank, 2014. The case for a Better Functioning Securitisation Market in the European Union. A Discussion Paper. ECB, Frankfurt am Main.

Elul, R., 2015. Securitization and Mortgage Default. Journal of Financial Services Research 49, 281309.

Financial Crisis Inquiry Commission, 2011. The Financial Crisis Inquiry Report. The Financial Crisis Inquiry Commission 663.

Gennaioli, N., Shleifer, A., Vishny, R., 2012. Neglected Risks, Financial Innovation, and Financial Fragility. Journal of Financial Economics 104, 452-468.

Goderis, B., Marsh, I., Vall Castello, J., Wagner, W., 2007. Bank Behaviour with Access to Credit Risk Transfer Markets. Bank of Finland, Helsinki.

Gokbayrak,O., L. Chua, 2009. Validating the Public EDFTM Model During the Credit Crisis in Asia and Europe Moody's Analytics (November).

Gorton, G.B., Pennacchi, G.G., 1995. Banks and Loan Sales: Marketing Nonmarketable Assets. Journal of Monetary Economics 35, 389-411.

Greenbaum, S.I., Thakor, A.V., 1987. Bank Funding Modes: Securitization versus Deposits. Journal of Banking and Finance 11, 379-401.

Haensel, D., Krahnen, J.P., 2007. Does Credit Securitization Reduce Bank Risk? Evidence from the European CDO Market. Goethe University, Frankfurt am Main.Instefjord, N., 2005. Risk and Hedging: Do Credit Derivatives Increase Bank Risk? Journal of Banking and Finance 29, 333345.

Jarrow, R., Li, L., Mesler, M., van Deventer, D., 2007. CDO Valuation: Fact and Fiction, Kamakura Corporation Paper.

Jessen.,C., Lando, D., 2015. Robustness of Distance-to-default, Journal of Banking and Finance 50, 493-505.Jiangli, W., Pritsker, M., Raupach, P., 2007. Banking and Securitization. FDIC, Washington DC.

Kamstra, M.J., Roberts, G.S., Shao, P., 2014. Does the Secondary Loan Market Reduce Borrowing Costs? Review of Finance 18, 1139-1181

Kara, A., Marques-Ibanez, D., Ongena, S., 2016. Securitization and lending standards: Evidence from the European wholesale loan market. Journal of Financial Stability 26, 107-127

Keys, B.J., Mukherjee, T.K., Seru, A., Vig, V., 2011. Did Securitization Lead to Lax Screening: Evidence from Subprime Loans 2001-2006. Quarterly Journal of Economics 125, 307-362.

Korablev, I., Qu, S., 2009. Validating the Public EDF Model Performance During the Recent Credit Crisis, Moody's Analytics (June).

Krahnen, J.P., Wilde, C., 2008. Risk Transfer with CDOs. Goethe University, Frankfurt am Main.

Krainer, J., Laderman, E., 2014. Mortgage Loan Securitization and Relative Loan Performance. Journal of Financial Services Research 45, 39-66.

Merton, R.C., 1974. On the Pricing of Corporate Debt: The Risk Structure of Interest Rates. Journal of Finance 29, 449-470.

Michalak, T.C., Uhde, A., 2013. Credit Risk Securitization and Bank Soundness: Evidence from the Microlevel for Europe. Quarterly Review of Economics and Finance 52, 272-285.

Morrison, A.D., 2005. Credit Derivatives, Disintermediation, and Investment Decisions. Journal of Business 78, 621-648.

Munves, D., Hamilton, D., Gokbayrak, O., 2009. The Performance of EDFs since the Start of the Credit Crisis. Moody's Analytics (June).

Nadauld, T.D., Weisbach, M.S., 2012. Did Securitization Affect the Cost of Corporate Debt? Journal of Financial Economics 105, 332-352.

Parlour, C.A., Plantin, G., 2008. Loan Sales and Relationship Banking. Journal of Finance 63, 12911314. 
Petersen, M.A., Rajan, R.G., 2002. Does Distance Still Matter? The Information Revolution in Small Business Lending. Journal of Finance 57, 2533-2570.

Piskorski, T., Seru, A., Vig, V., 2010. Securitization and Distressed Loan Renegotiation: Evidence from the Subprime Mortgage Crisis. Journal of Financial Economics 97, 369-397.

Rosenbaum, P.R., Rubin, D.B., 1983. The Central Role of the Propensity Score in Observational Studies for Causal Effects. Biometrika 70, 41-55.

Rubin, D.B., Thomas, N., 2000. Combining Propensity Score Matching with Additional Adjustments for Prognostic Covariates. Journal of the American Statistical Association 95, 573-585.

Santos, T., 2015. Credit Booms: Implications for the Public and the Private Sector. Bank for International Settlements Working Papers 481.

Shivdasani, A., Wang, Y., 2011. Did Structured Credit Fuel the LBO Boom? Journal of Finance 66, 1291-1328.

Sufi, A., 2007. Information asymmetry and financing arrangements: Evidence from syndicated loans. Journal of Finance 62, 629-668.

Wagner, W., 2007. The Liquidity of Bank Assets and Banking Stability. Journal of Banking and Finance 31, 121-139.

Wang, Y., Xia, H., 2015. Do Lenders Still Monitor When They Can Securitize Loans? Review of Financial Studies 28, 2354-2391. 
Table 1

Descriptive Statistics

\begin{tabular}{|c|c|c|c|c|c|c|c|}
\hline \multirow{2}{*}{$\begin{array}{l}\text { Panel A } \\
\text { Loan characteristics }\end{array}$} & \multicolumn{3}{|c|}{ Non-securitized $(\mathrm{N}=429)$} & \multicolumn{3}{|c|}{ Securitized $(\mathrm{N}=89)$} & \multirow{2}{*}{$\begin{array}{c}\begin{array}{c}\text { Mean } \\
\text { comparison }\end{array} \\
\text { t-values } \\
\end{array}$} \\
\hline & Mean & Median & Std. dev & Mean & Median & Std. dev & \\
\hline Spread & 138 & 87.5 & 160 & 310 & 275 & 181 & $-9.01 * * *$ \\
\hline Size (million Euro) & 670 & 242 & 1,328 & 435 & 170 & 819 & 1.60 \\
\hline Maturity & 5.8 & 5.6 & 2.1 & 8.1 & 8 & 1.4 & $-9.88 * * *$ \\
\hline Syndicate size & 13.9 & 11 & 10.1 & 13.4 & 10 & 11.4 & 0.41 \\
\hline Securitization active banks & 0.69 & 0.69 & 0.18 & 0.69 & 0.64 & 0.19 & -0.00 \\
\hline$E D F$ & 0.41 & 0.08 & 1.31 & 0.17 & 0.05 & 0.31 & $1.72 *$ \\
\hline
\end{tabular}

\section{Panel B - Percentage of loans}

Secured

Subordinated

Sponsored

Instrument type

Term loan

Term loan A

Term loan B

Term loan $\mathrm{C}$

Revolving credit

Credit facility

Other

Risk and credit ratings

Leveraged

Investment grade

Highly leveraged

Rated

\begin{tabular}{c} 
Non-securitized \\
\hline $35.79 \%$ \\
$4.22 \%$ \\
$53.47 \%$
\end{tabular}

$29.01 \%$

$9.82 \%$

$5.82 \%$

$4.19 \%$

$29.80 \%$

$12.82 \%$

$8.54 \%$

$53.82 \%$

$45.51 \%$

$0.67 \%$

$12.79 \%$
Securitized

$52.85 \%$

$17.99 \%$

$97.02 \%$

$14.64 \%$

$16.13 \%$

$28.54 \%$

$26.18 \%$

$4.34 \%$

$0.12 \%$

$10.05 \%$

$98.88 \%$

$1.12 \%$

$0.00 \%$

$6.45 \%$ 


\section{Table 2}

\section{Probability of loan securitization and default risk at loan issuance}

This table presents coefficient estimates for logit regression estimating the probability of loan securitization within one year of loan issuance. $E D F$ is the expected default frequency, computed by Moody's KMV, at the time of loan issuance. We control for observable loan and syndicate characteristics at the time of loan origination. Loan characteristics include: spread (basis point over LIBOR), size, maturity, if the loan is secured, if the loan is subordinated, if the loan is sponsored, loan rating, type of loan and if the loan is leveraged. Syndicated characteristics include the number of the banks in the lending syndicate and the ratio of securitization active banks within the syndicate over the total number of banks. Bank characteristics include average profitability of the banks within the syndicate and controls for possible lead bank effects on the syndicate. Loan purpose is controlled for using dummy variables (categorized as general corporate use, capital structure, project finance, transport finance, corporate control and property finance). Business Industry is controlled for using dummy variables (categorized as construction and property, high-tech industry, infrastructure, population related services, state, manufacturing and transport). Year dummy variables control for the macroeconomic conditions. Robust standard errors are reported in parenthesis. ${ }^{* * *}, * *$ and $*$ represents significance levels at $1 \%, 5 \%$ and $10 \%$, respectively.

\section{$E D F$}

Controls for:

Loan characteristics

Yes

Syndicate characteristics

Yes

Bank characteristics

Yes

Loan purpose

Yes

Business industry

Yes

Year dummy variables

Yes

\section{Constant}

Number of observations

Pseudo R-squared 


\section{Table 3}

\section{Probability of loan securitization and change in default risk after loan issuance}

This table presents coefficient estimates for logit regressions estimating the probability of loan securitization within one year of loan issuance. $E D F$ is the expected default frequency, computed by Moody's KMV, at the time of loan issuance. $\triangle E D F_{A}$ are changes in borrower credit quality to a certain period after issuance. For example if the loan is issued in 2005 then $\triangle E D F_{A}$ within 1 year of the borrower equals the $E D F$ in 2006 minus the $E D F$ in 2005 divided by $E D F$ in 2005 . We control for observable loan and syndicate characteristics at the time of loan origination. Loan characteristics include: spread (basis point over LIBOR), size, maturity, if the loan is secured, if the loan is subordinated, if the loan is sponsored, loan rating, type of loan and if the loan is leveraged. Syndicated characteristics include the number of the banks in the lending syndicate and the ratio of securitization active banks within the syndicate over the total number of banks. Bank characteristics include average profitability of the banks within the syndicate and controls for possible lead bank effects on the syndicate. Loan purpose is controlled for using dummy variables (categorized as general corporate use, capital structure, project finance, transport finance, corporate control and property finance). Business Industry is controlled for using dummy variables (categorized as construction and property, high-tech industry, infrastructure, population related services, state, manufacturing and transport). Year dummy variables control for the macroeconomic conditions. Robust standard errors are reported in parenthesis. $* * *, * *$ and $*$ represents significance levels at $1 \%, 5 \%$ and $10 \%$, respectively.

\begin{tabular}{cccc}
\hline & I & II & III \\
\hline$E D F$ & $-0.952 * * *$ & $-1.327 * * *$ & $-1.259 * *$ \\
& -0.289 & -0.331 & -0.587
\end{tabular}

$\triangle E D F_{A}$ within

$\begin{array}{cc}1 \text { year } & 0.899 * * \\ & -0.399\end{array}$

2 year

3 year

Controls for:

Loan characteristics
Syndicate characteristics
Bank characteristics
Loan purpose
Business industry
Year dummy variables

Constant

Number of observations 


\section{Table 4}

\section{Loan securitization and change in default risk from issuance to crisis}

This table presents coefficient estimates for logit regressions estimating the probability of loan securitization within one year of loan issuance. $E D F$ is the expected default frequency, computed by Moody's KMV, at the time of loan issuance. $\triangle E D F_{B}$ are changes in borrower credit quality from issuance to different periods of the financial crisis. For example if the loan is issued in 2006 then $\Delta$ in $E D F_{B}$ from the loan issuance to 2008 equals the $E D F$ in 2008 minus the $E D F$ in 2006 divided by $E D F$ in 2006. We control for observable loan and syndicate characteristics at the time of loan origination. Loan characteristics include: spread (basis point over LIBOR), size, maturity, if the loan is secured, if the loan is subordinated, if the loan is sponsored, if the loan is rated, type of loan and leveraged loan. Syndicated characteristics include the number of the banks in the lending syndicate and the ratio of securitization active banks within the syndicate over the total number of banks. Bank characteristics include average profitability of the banks within the syndicate and controls for possible lead bank effects on the syndicate. Loan purpose is controlled for using dummy variables (categorized as general corporate use, capital structure, project finance, transport finance, corporate control and property finance). Business industry is controlled for using dummy variables (categorized as construction and property, high-tech industry, infrastructure, population related services, state, manufacturing and transport). Year dummy variables control for the macroeconomic conditions. Robust standard errors are reported in parenthesis. ***,** and * represents significance levels at $1 \%, 5 \%$ and $10 \%$, respectively.

\begin{tabular}{|c|c|c|c|}
\hline & $\mathrm{I}$ & II & III \\
\hline$E D F$ & $\begin{array}{c}-1.100^{* *} \\
(0.554)\end{array}$ & $\begin{array}{l}-1.076^{*} \\
(0.591)\end{array}$ & $\begin{array}{c}-0.736^{* *} \\
(0.301)\end{array}$ \\
\hline \multicolumn{4}{|c|}{$\Delta E D F_{B}$ from the loan issuance to } \\
\hline 2008 & $\begin{array}{c}0.293^{* *} \\
(0.143)\end{array}$ & & \\
\hline 2009 & & $\begin{array}{c}0.153 * * * \\
(0.056)\end{array}$ & \\
\hline 2010 & & & $\begin{array}{c}0.112^{* *} \\
(0.044)\end{array}$ \\
\hline \multicolumn{4}{|l|}{ Controls for: } \\
\hline Loan characteristics & Yes & Yes & Yes \\
\hline Syndicate characteristics & Yes & Yes & Yes \\
\hline Bank characteristics & Yes & Yes & Yes \\
\hline Loan purpose & Yes & Yes & Yes \\
\hline Business industry & Yes & Yes & Yes \\
\hline Year dummy variables & Yes & Yes & Yes \\
\hline Constant & $\begin{array}{c}-13.995^{* * *} \\
(2.204)\end{array}$ & $\begin{array}{c}-15.132 * * * \\
(2.511)\end{array}$ & $\begin{array}{c}-15.247 * * * \\
(2.482)\end{array}$ \\
\hline Number of observations & 446 & 417 & 428 \\
\hline Pseudo R-squared & 0.57 & 0.61 & 0.61 \\
\hline
\end{tabular}




\section{Table 5}

\section{Loan securitization and change in default risk during financial crisis}

\begin{tabular}{|c|c|c|c|}
\hline \multicolumn{4}{|c|}{$\begin{array}{l}\text { This table presents coefficient estimates for logit regressions estimating the probability of loan securitization within one year } \\
\text { of loan issuance. } E D F \text { is the expected default frequency, computed by Moody's KMV, at the time of the loan issuance. } \triangle E D F_{C} \\
\text { are changes in borrowor credit quality during the financial crisis. We control for observable loan and syndicate characteristics } \\
\text { at the time of the loan origination. Loan characteristics include: spread (basis point over LIBOR), size, maturity, if the loan is } \\
\text { secured, if the loan is subordinated, if the loan is sponsored, if the loan is rated, type of loan and if the loan is leveraged. } \\
\text { Syndicated characteristics include the number of the banks in the lending syndicate and the ratio of securitization active banks } \\
\text { within the syndicate over the total number of banks. Bank characteristics include average profitability of the banks within the } \\
\text { syndicate and controls for possible lead bank effects on the syndicate. Loan purpose is controlled for using dummy variables } \\
\text { (categorized as general corporate use, capital structure, project finance, transport finance, corporate control and property } \\
\text { finance). Business Industry is controlled for using dummy variables (categorized as construction and property, high-tech } \\
\text { industry, infrastructure, population related services, state, manufacturing and transport). Year dummy variables control for the } \\
\text { macroeconomic conditions. Robust standard errors are reported in parenthesis. }{ }^{* * *},{ }^{* *} \text { and } * \text { represents significance levels at } \\
1 \%, 5 \% \text { and } 10 \% \text {, respectively. }\end{array}$} \\
\hline & $\mathrm{I}$ & II & III \\
\hline$E D F$ & $\begin{array}{c}-1.273 * * \\
(0.581)\end{array}$ & $-1.095^{*}$ & $\begin{array}{c}-0.748^{* *} \\
(0309)\end{array}$ \\
\hline \multicolumn{4}{|l|}{$\Delta E D F_{C}$ from $Q 3: 2007$ to } \\
\hline 2008 & $\begin{array}{l}0.281^{*} \\
(0.157)\end{array}$ & & \\
\hline 2009 & & $\begin{array}{c}0152^{* * * *} \\
(0.056)\end{array}$ & \\
\hline 2010 & & & $\begin{array}{c}0.114 * * * \\
(0.044)\end{array}$ \\
\hline \multicolumn{4}{|l|}{ Controls for: } \\
\hline Loan characteristics & Yes & Yes & Yes \\
\hline Syndicate characteristics & Yes & Yes & Yes \\
\hline Bank characteristics & Yes & Yes & Yes \\
\hline Loan purpose & Yes & Yes & Yes \\
\hline Business industry & Yes & Yes & Yes \\
\hline Year dummy variables & Yes & Yes & Yes \\
\hline Constant & $\begin{array}{c}-13.9 * * * \\
(2.206)\end{array}$ & $\begin{array}{c}-15.1 * * * \\
(2.516)\end{array}$ & $\begin{array}{c}-15.3 * * * \\
(2.490)\end{array}$ \\
\hline No of observations & 444 & 412 & 423 \\
\hline Pseudo R-squared & 0.57 & 0.61 & 0.61 \\
\hline
\end{tabular}




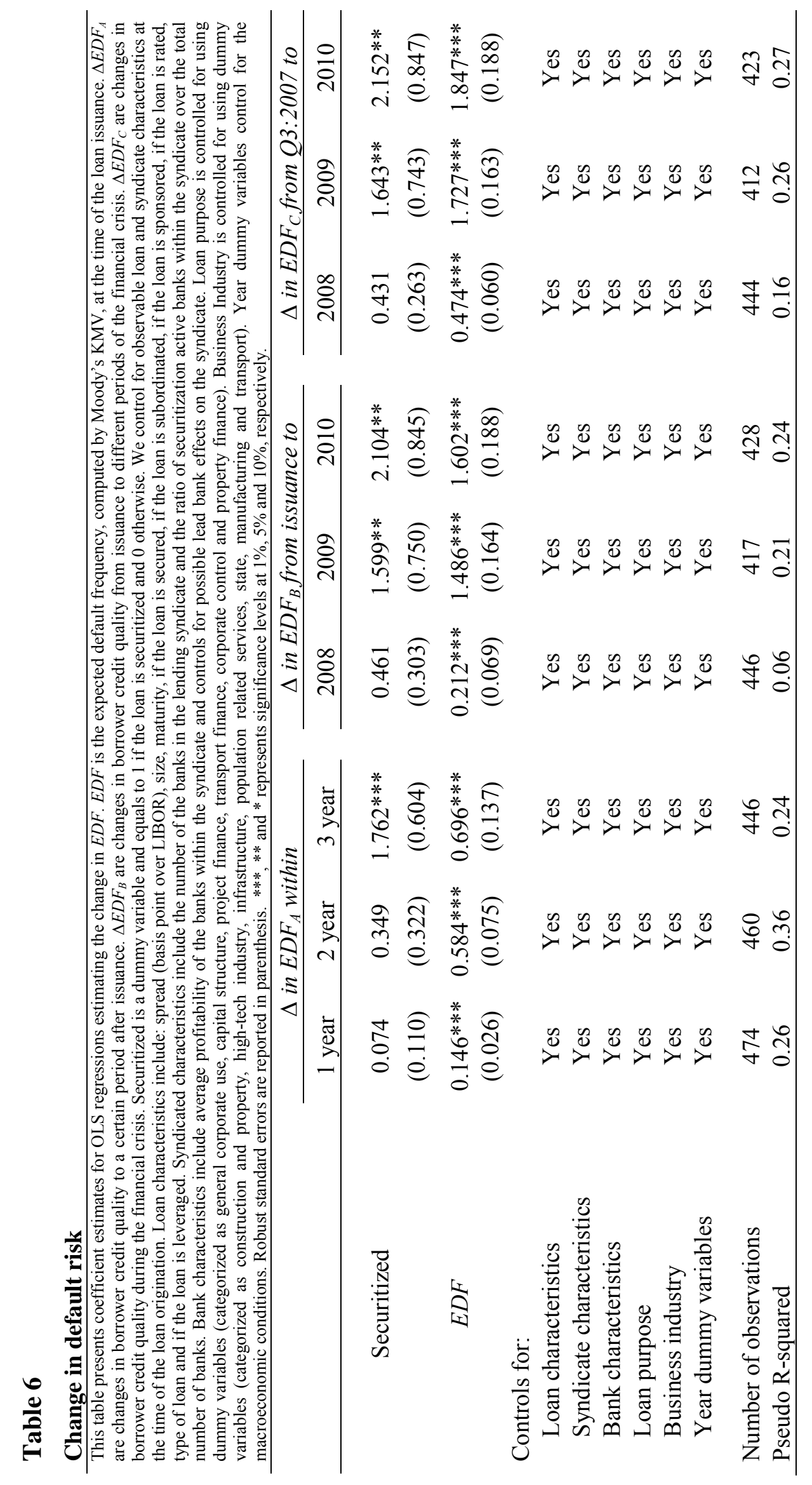



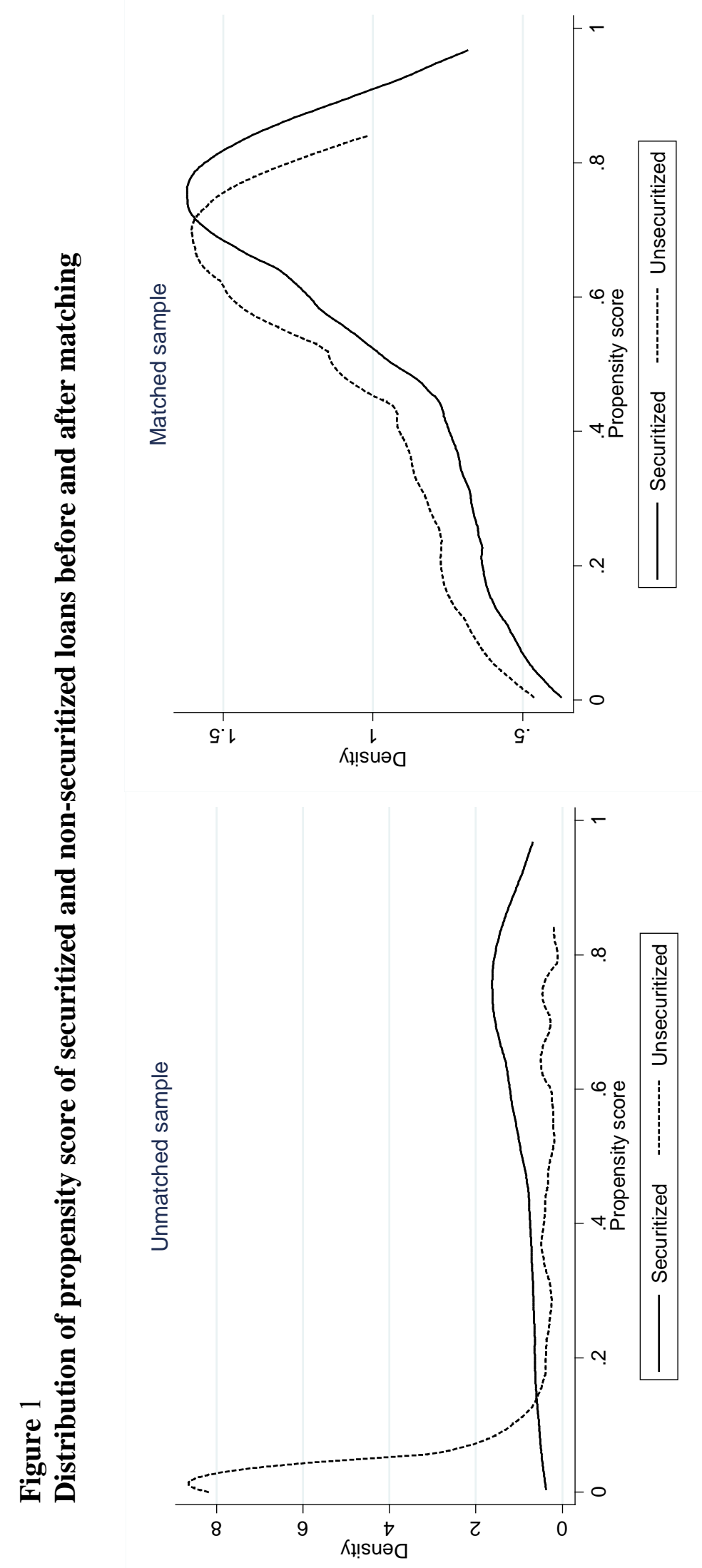


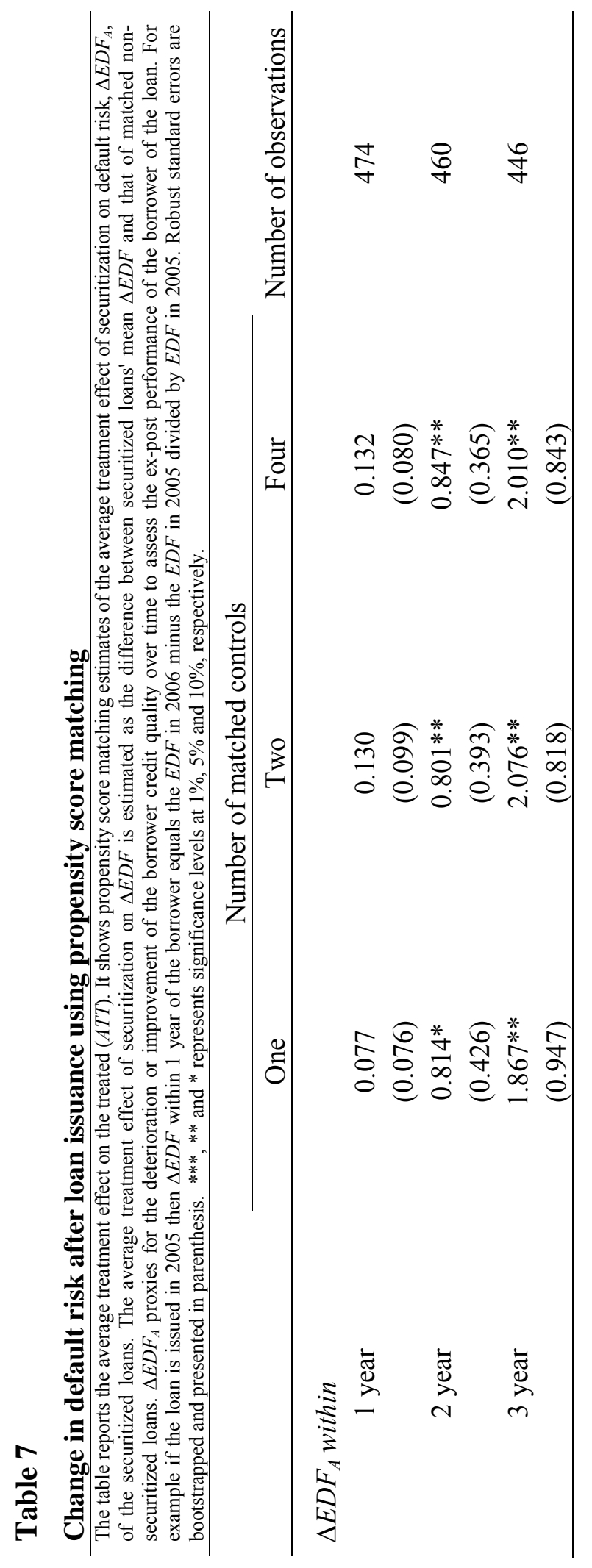




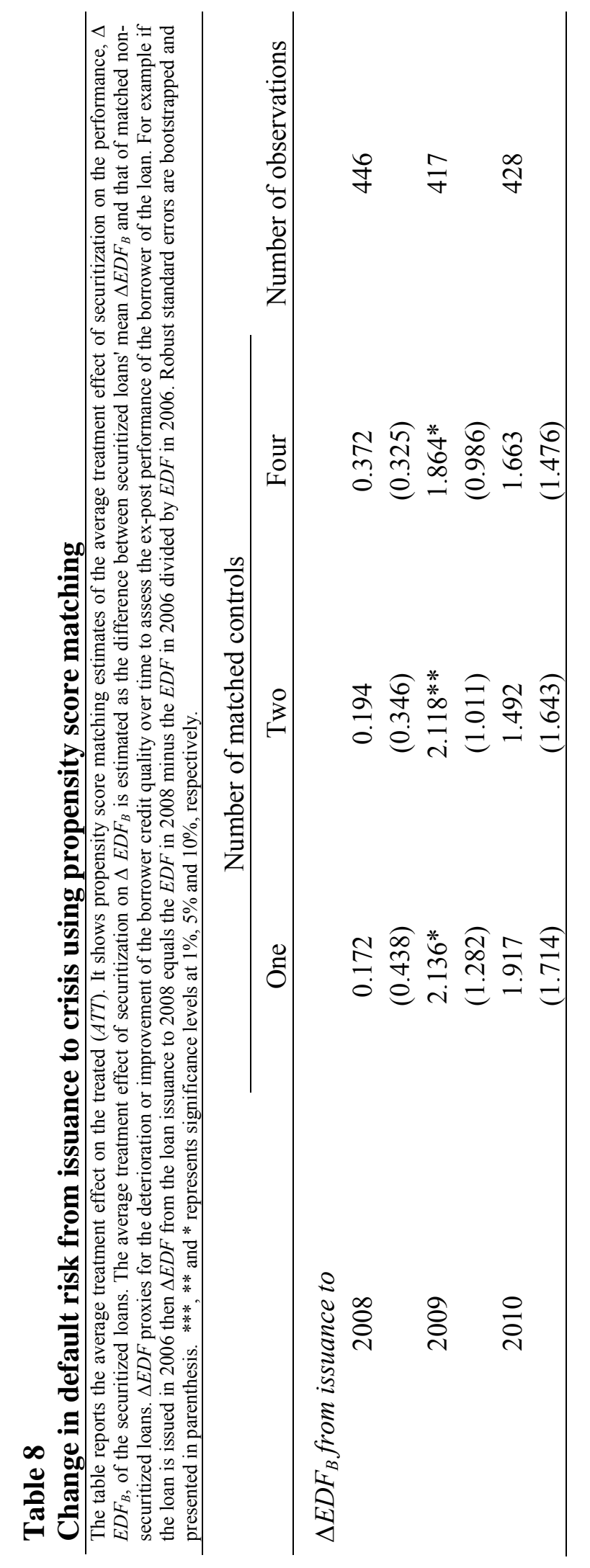




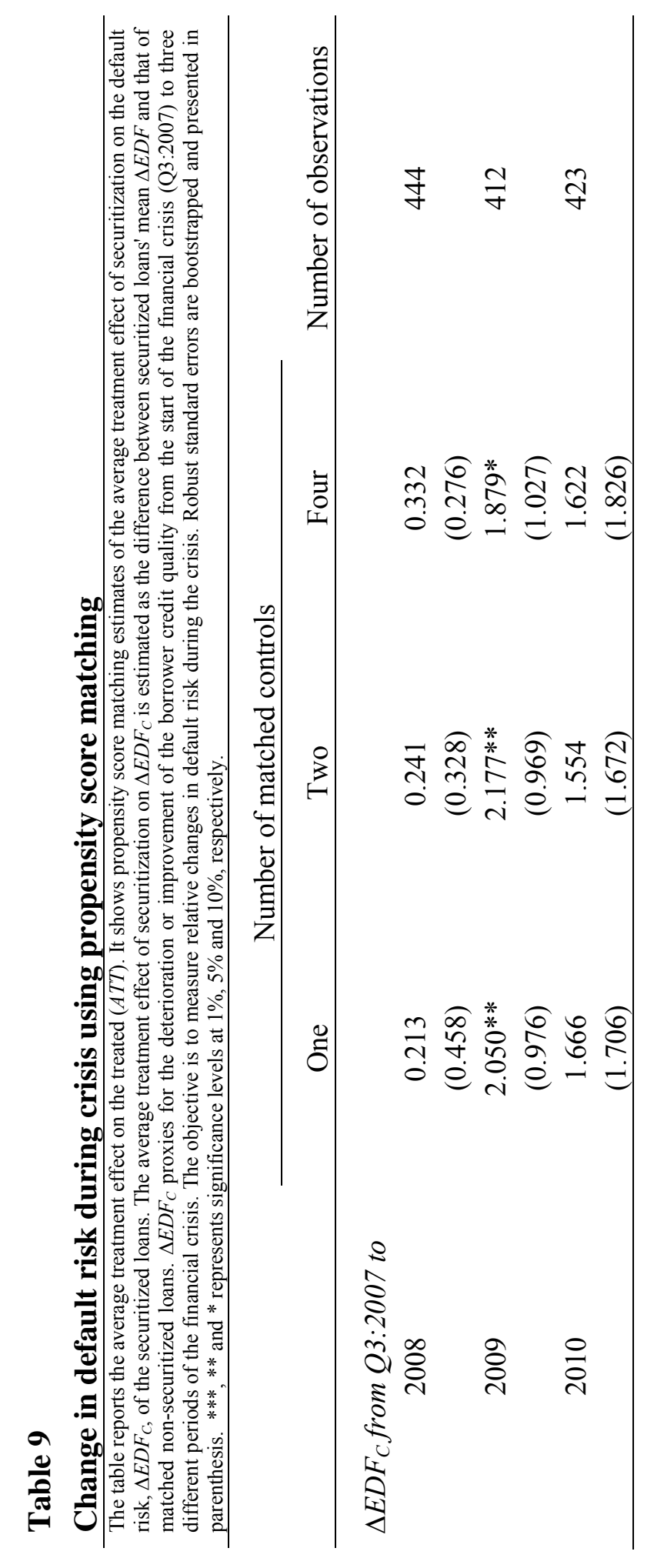




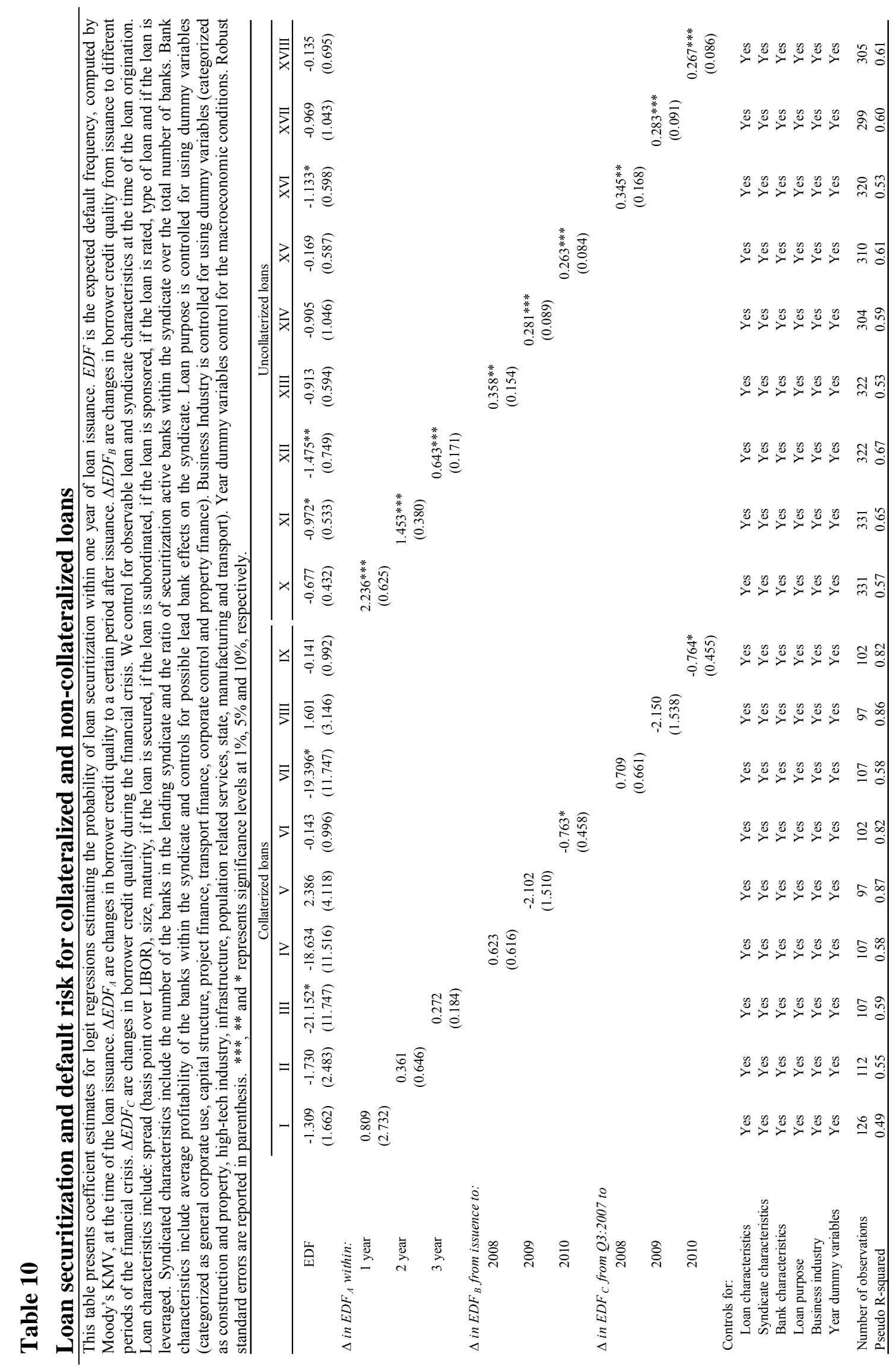




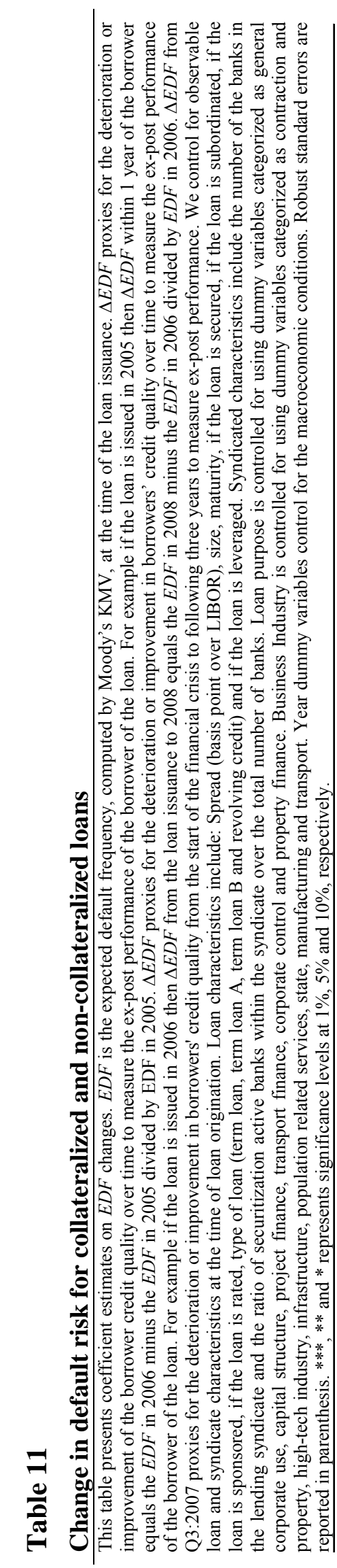

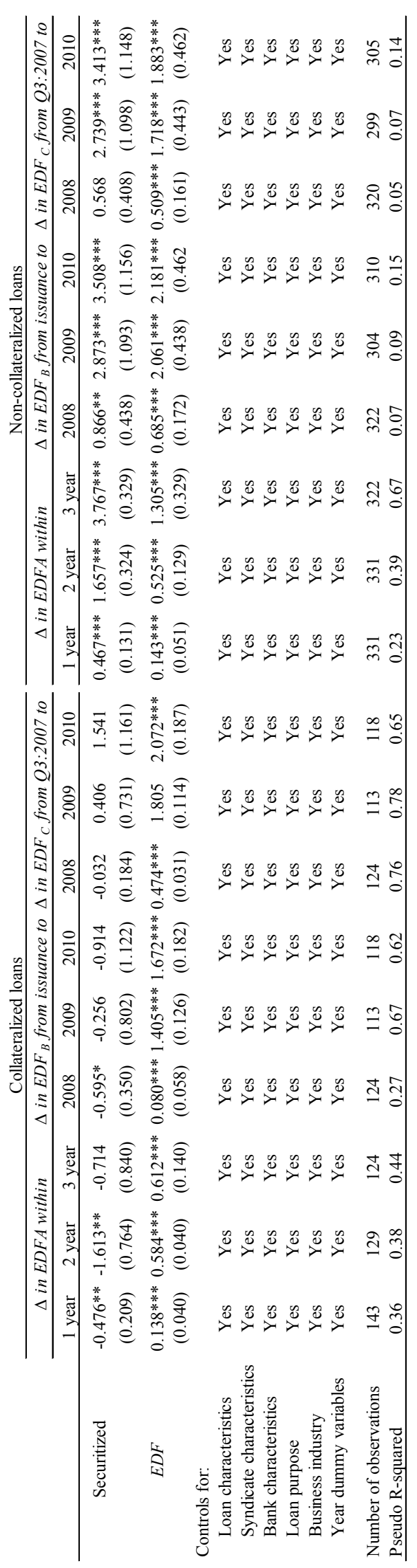


Table 12

Change in default risk for collateralized and non-collateralized with matched sample using propensity scores

The table reports the average treatment effect on the treated $(A T T)$. It shows propensity score matching estimates of the average treatment effect of securitization on the default risk, $\triangle E D F$, of the securitized loans. The average treatment effect of securitization on $\triangle E D F$ is estimated as the difference between securitized and matched non-securitized loans. $\triangle E D F_{A}$ are changes in borrowers' credit quality to a certain period after issuance. For example if the loan is issued in 2005, $\triangle E D F$ within 1 year equals the $E D F$ in 2006 minus the $E D F$ in 2005 divided by $E D F$ in 2005. $\triangle E D F_{B}$ are changes in borrower credit quality from issuance to different periods of the financial crisis. For example if the loan is issued in 2006 then $\triangle E D F$ from the loan issuance to 2008 equals the $E D F$ in 2008 minus the $E D F$ in 2006 divided by $E D F$ in $2006 . \triangle E D F_{C}$ are changes in borrower credit quality during the financial crisis. Robust standard errors are bootstrapped and presented in parenthesis. ***,** and * represents significance levels at $1 \%, 5 \%$ and $10 \%$, respectively.

\begin{tabular}{ccccc}
\multicolumn{2}{c}{ Collateralized loans } & & \multicolumn{2}{c}{ Non-collateralized loans } \\
\hline ATT & $\begin{array}{c}\text { Number of } \\
\text { observations }\end{array}$ & & Number of \\
\cline { 4 - 5 } & & & $A T T$ & observations \\
\hline
\end{tabular}

$\triangle E D F_{A}$ within

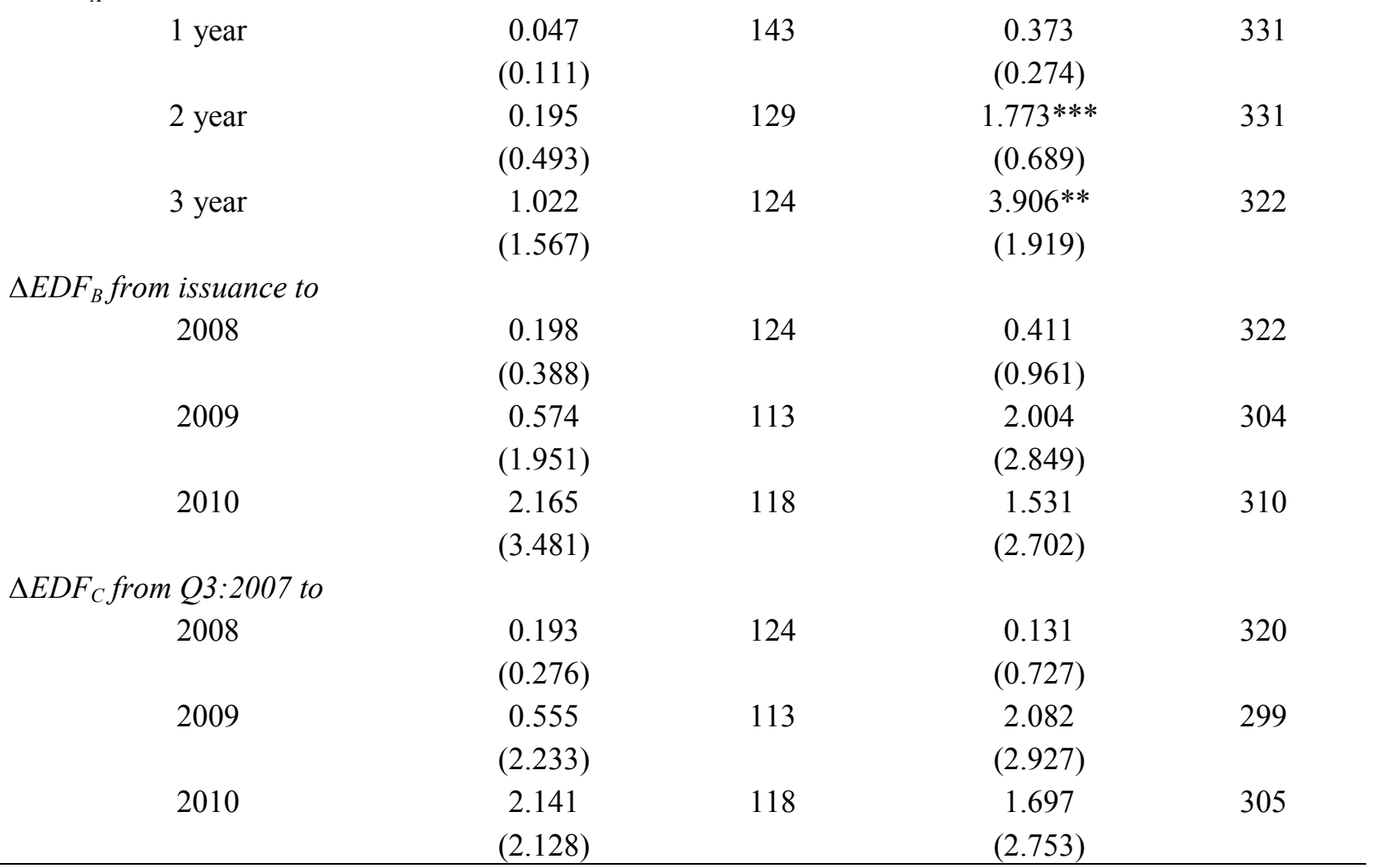

$\triangle E D F_{B}$ from issuance to 


\section{Acknowledgements}

We are grateful to an anonymous referee as well as to Peter Lindner, Giovanni Dell'Ariccia, Alfonso Del Giudice, Soledad Martinez Peria and the colleagues at the IMF's Macro Financial Research division for their kind hospitality and fruitful discussions. We also thank Rajeev H. Dehejia, Jose Luis Peydro, Alex Popov, John Rogers and Joao Santos, for helpful comments or discussions. Our thanks also to participants at seminars held at the European Central Bank (ECB), World Bank, Loughborough University, University of Hull, 6th IFABS 2014 Lisbon conference on "Alternative Futures for Global Banking: Competition, Regulation and Reform" and X Seminar on "Risk, Financial Stability and Banking" organized by the Banco Central of Brazil, Wolpertinger 2016 conference and 2016 PortsmouthFordham conference on "Banking and Finance" for their useful comments and discussions. We are also most grateful to Raffaele Passaro and Luiz Paulo Fichtner for their help with the initial data and for providing us with technical suggestions. We would also like to thank Oliver Goß and Priti Thanki from Standard and Poor's and, in particular, Jean-Paul Genot ( $\dagger$ ) for their invaluable help finding data on securitized syndication credit from all major securitization trustees in Europe. This work was completed while David Marques-Ibanez was at the IMF's Macro Financial Division of the Research Department. The opinions expressed in this paper are those of the authors only and do not necessarily reflect those of the IMF or the ECB.

\section{Alper Kara}

Loughborough University, School of Business and Economics Loughborough, United Kingdom; email: a.kara@lboro.ac.uk

\section{David Marques-Ibanez}

European Central Bank, Financial Research Division, Frankfurt am Main, Germany; email: David.Marques@ecb.int

\section{Steven Ongena}

University of Zürich, Zürich, Switzerland; email: steven.ongena@bf.uzh.ch

\section{(C) European Central Bank, 2017}

Postal address

Telephone

Website
60640 Frankfurt am Main, Germany
+496913440

www.ecb.europa.eu

All rights reserved. Any reproduction, publication and reprint in the form of a different publication, whether printed or produced electronically, in whole or in part, is permitted only with the explicit written authorisation of the ECB or the authors.

This paper can be downloaded without charge from www.ecb.europa.eu, from the Social Science Research Network electronic library or from RePEc: Research Papers in Economics. Information on all of the papers published in the ECB Working Paper Series can be found on the ECB's website.

ISSN

ISBN

$$
1725-2806 \text { (pdf) }
$$$$
\text { 978-92-899-2731-4 (pdf) }
$$

DOI

EU catalogue No
10.2866/696711 (pdf)

QB-AR-17-021-EN-N (pdf) 